DOI URL: https://doi.org/10.3126/jbssr.v4i2.29484

\title{
Service Quality Dimensions Influencing Online Buying Satisfaction Level of Customers in the Kathmandu Valley
}

\author{
Raunak Bohra ${ }^{1}$ \\ Puja Tamang ${ }^{2}$
}

\begin{abstract}
Article History
Received 2 Oct 2019

Reviewed 28 Oct 2019

Revised 15 Nov 2019

Revised 15 Dec 2019

Accepted 28 Dec 2019

\section{Keywords}

customer satisfaction, descriptive analysis, e-commerce, inferential analysis, internet shopping online shopping
\end{abstract}

Journal of Business and Social Sciences Research (ISSN: 25422812). Vol IV, No. 2 , December 2019

\section{Abstract}

This paper examines the factors influencing customer's online shopping buying satisfaction level inside the Kathmandu Valley. It establishes a relationship between service quality dimensions with customer satisfaction in Nepalese online buying through correlation analysis. Seven service quality dimensions were selected for this research. They are information quality, usability, reliability, responsiveness, assurance, transaction security and personalisation. Data gathering was carried out developing a structured questionnaire which was distributed both through online and printed form using a convenience sampling method. The study has analysed the responses of 160 online shoppers (aged above 18 years) residing in the. The study confirms the absence of significant relationship between website usability and responsiveness while shows a positively significant relationship between other service quality (SERVQUAL) dimensions taken for this research. The proposed model in this study helps to ascertain the factors that influence online buying satisfaction level. Further, study concludes that while shopping online, websites with good layout and interaction helps promote customer satisfaction. Similarly, website reliability such as timely delivery of products, being truthful about its offerings, and fast delivery are considered as important elements for customer satisfaction.

\footnotetext{
${ }^{1}$ Mr. Bohra is an MBA graduate from Ace Institute of Management, Pokhara University and he is involved in the business of online marketing and superior bath fittings.

${ }^{2}$ Ms Tamang holds an MBA degree from Lincoln International College. She is associated with the Ace Institute of Management as Research Officer at Ace Research Centre, and pursuing MPhil at Kathmandu University School of Management. She can be contacted at puja@ace.edu.np
} 


\section{Introduction and Study Objectives}

Numerous products and services are ordered through online e-commerce websites and delivered through the internet, the most visible and explosive information technology tool in this dynamic technological world. Moreover, the Internet offers an interactive function with its customers and enables electronic service to move to the forefront of technology priorities. An e-service is an interactive, content-centred and Internet-based customer service, driven by the customer and integrated with related organisational customer support processes and technologies to strengthen customer-service provider relationships.

Regardless of the growing trend of internet shopping websites in Nepalese context, people using the service are not sufficient enough. The use of the internet is high and it's growing but the growth of internet shopping websites is minimal. Muncha.com was one of the first companies to start the trend of online shopping and e-commerce in Nepal in 2000 (Sthapit, 2016). However, till date, the challenges it faced in the online business are still the same. Due to a lack of knowledge, awareness and online payment system among customers, the maximum use of this service has not been able to begin. Therefore, by acknowledging the various factors that influence the customer's online buying satisfaction level, steps can be taken in the right direction to enhance the satisfaction levels of customers shopping online.

The presence of the internet is booming in various companies during the last decade. In order to establish a web presence, companies have accepted and adopted advanced web technologies. Such a web presence not only supports traditional activities but also helps in grabbing new opportunities that arise from using the web as a new channel to conduct business-to-customer electronic commerce transactions. The establishment of a web presence enables companies to reach global presence with minimal operating costs, offering information in depth and providing their customer superior electronic service quality. On the other hand, the web introduces industry to increased competition that makes satisfying customers difficult and a challenging issue.

Customer satisfaction has become a major concern among all businesses. A satisfied customer is more likely to be loyal with the same company, and effective loyalty-building strategies enable e-business to grow in size and population. One way of enhancing customer satisfaction is by offering superior e-services quality. Thus, customer satisfaction levels while shopping online is a vital field that needs to be studied in the context of Nepalese customers.

\section{Literature Review}

Parasuraman, Zeithaml, and Berry (1985) suggested that a service-quality model develops a standard instrument to measure consumers' service quality perceptions. It assumed that perception of quality of consumers are influenced by a series of distinct gaps that occurs on the market side. Further, they added that segmenting consumers based on their expectations on service quality is 
worth exploring and useful as well. The model helps in developing conceptual framework in an area where little prior research has been done. SERVQUAL model is based on analysis of qualitative data by conducting in-depth executive interviews and consumer focus groups. This is a method that is suggested for any marketing theory development. Thus, the conceptual framework that emerges from such an approach is implied for future study.

Pappas, Pateli, Giannakos, and Chrissikopoulo (2013) researched to find the satisfaction levels in online shopping. The research concluded that while shopping online, there are moderating effects between performance expectancy and satisfaction as well as between satisfaction levels and intention to purchase. The study also demonstrated that while customer experience the relationship between performance expectancy and satisfaction is strengthened, it weakens the relationship of satisfaction with repurchase of products and services online.

Elias (2015) opined that quality of online services plays an increasingly important role in customer's online buying satisfaction levels. Among the five service quality factors were selected: tangibility, information quality, responsiveness, trust and personalisation, three service quality factors - tangibility, trust, and personalisation have significant influences on customer satisfaction.

Tandon, Kiran, and Sah (2015) and Zhang (2016) tried to analyse what role do perceived usability and perceived usefulness play in customer satisfaction towards online shopping in countries India and China respectively. The findings of the study revealed that website functionality is a major factor that positively affects perceived usability. Similarly, the perceived usefulness and perceived usability both positively affect customer satisfaction. The findings showed that the influences of technological factors, product factors, sales promotion towards customer attitude and loyalty were significantly mediated by customer satisfaction. Also, customer satisfaction had a direct significant effect on customer attitude and an indirect effect on loyalty, while customer attitude had a direct effect on loyalty in online shopping.

Various researchers have researched to understand how different factors affect customer online buying satisfaction. The results concluded with evidence that service quality of online shops and express deliveries have positive impacts on customer satisfaction. Along with that, there is also a high correlation coefficient between the online shop and the delivery company. Therefore, they state that to improve customer satisfaction levels, a high-quality delivery service is crucial (Kloppers, 2014; Xiao, 2017)

Kharel (2018) conducted research to identify how various factors influence online brand trust from buyers in the Kathmandu valley. The study found that although respondents consider time-saving to be the important factor, only more than half of the respondents used online shopping to purchase products and services thrice in a year. Respondents preferred to buy tickets online than any other commodity. Lastly, brand reputation was the most influencing factor while website information was not as important for influencing customer's online purchasing decisions. 
Delima and Ashary (2019) analysed how different variables such as service quality, product quality, price, brand image, and promotion affect customer satisfaction levels and their loyalty towards an online shop. The research was conducted in Jakarta. The results of the findings were that service quality, product quality, price, promotion and brand image are positive and have a significant impact on consumer satisfaction and consumer loyalty.

Many customers now prefer to go to the internet and browse online websites to purchase various products, services than ever before. This trend is expected to grow as the internet proliferates into deeper parts of the country covering more areas, thus allowing more people to get on to the internet. Till now in various countries around the world, various researches have been conducted to understand how customer online buying satisfaction is affected by various determinants. However, such a study has not been conducted in Nepal so far. Therefore, it remains to be seen how residents of Kathmandu valley feel about online shopping websites and how SERVQUAL dimensions affect their satisfaction levels. This research work is expected to fill the gaps to minimise between literature and the level of customer satisfaction of Nepalese customers with online shopping.

\section{The Conceptual Framework}

The framework of this study has been developed based on the study of Swaid and Wigand (2007). This research has been motivated by the growing interest in online shopping by residents of the Kathmandu valley. This research attempts to find out various roles that online marketing can play to influence customer's shopping behaviour and perception for online e-commerce businesses. The findings include key dimensions of e-commerce service quality which are website usability, information quality, reliability, responsiveness, assurance and personalisation and how these factors influence the customer online buying satisfaction levels.

Website Information
Website Usability
Website Reliability
Website Responsiveness
Website Assurance
Website Transaction Security
Website Personalisation

Note. The framework is based on Swaid and Wigand (2007)

Figure 1. Conceptual Framework showing SERVQUAL Dimensions influencing Online Buying Satisfaction Level of Customers 
Website information is the tangible aspect of the SERVQUAL model that corresponds to how well the website is able to convey the necessary information to customers' regarding the products and services. Website usability is another tangible aspect of the SERVQUAL model that corresponds to how well the website is functioning including the search function, layout of categories and the overall website's organisation. Website reliability in the SERVQUAL model is the company's ability to do what it promises. Reliability is considered as the proper functioning of the website and the ability to perform the promised services dependably and accurately in the context of the web. Website responsiveness is measured by the promptness with which the e-retailer responds to customer queries and issues. Instead of the technical advancements in internet security such as cryptography, digital signatures, certificates, online customers are still concerned about security problems while buying online. Though, it has been found that perceived assurance has a significant influence on the intentions to purchase online. Another security concern while purchasing online is online payments. The more secure the transaction is, the more satisfied customers are. Likewise, empathy in the SERVQUAL model is defined as the individualised attention that companies offer their target customers. In this regard, empathy in the context of the web becomes the personalisation construct. The Internet is bidirectional communication. Therefore, online firms are empowered to identify the customer's shopping habits, preferences and needs. Offering customised goods and recommendations that meet customers' preferences influences their satisfaction and intentions to repurchase.

\section{Research Methods}

The study has a descriptive and analytical research methodology as this research describes characteristics of population or the phenomena to be studied and also involves the evaluation of information generated through research. The broad area of investigation for this study is online buying satisfaction level. So, for the purpose of this study, the units of analysis comprise online users for shopping with the age group of above 18 residing in three districts of the Kathmandu Valley, i.e., Kathmandu, Lalitpur and Bhaktapur.

A total of 160 usable responses has been finalised for data analysis which includes 60 from Kathmandu and 50 from Lalitpur and Bhaktapur districts each. The responses collected seek to maintain balance in terms of gender as well as an effort to study the relationship in different gender groups. Convenience sampling was used to gather the necessary data for this study. Both primary and secondary data sources were used for this research. While the study and its findings are based upon the data collected primarily through a structured questionnaire designed, various secondary sources like published articles, websites, and research reports were referred. 


\section{Data Analysis and Discussion}

This section presents and discusses the data analysis and results.

Table 1

Demographic Characteristics of Respondents

\begin{tabular}{llll}
\hline Variables & Classification of variables & Frequency & Per cent \\
\hline Gender & Male & 105 & 65.6 \\
Age & Female & 55 & 34.4 \\
& 18-20 years & 33 & 20.6 \\
& 21 - 29 Years & 46 & 28.8 \\
& 30 - 39 Years & 39 & 24.4 \\
& $40-49$ Years & 24 & 15 \\
Academic Qualification & 50 Years and above & 18 & 11.3 \\
& Post Graduate & 12 & 7.5 \\
& Graduate & 45 & 28.1 \\
Occupation & Under-Graduate & 53 & 33.1 \\
& Up to Intermediate & 50 & 31.3 \\
& Student & 37 & 23.1 \\
Income Level & Business Person & 51 & 31.9 \\
& Service Holder & 40 & 25 \\
& Others & 32 & 20 \\
& Below Rs. 15000 & 21 & 13.1 \\
& Rs.15000 - 25000 & 29 & 18.1 \\
& Rs.25001 -35000 & 33 & 20.6 \\
& Rs. 35001 - 45000 & 37 & 23.1 \\
& Above 45000 & 40 & 25 \\
\hline
\end{tabular}

Note. Data from survey conducted in 2017

The respondents surveyed were found to have used at least five websites for buying online; namely Kaymu/Daraz, SastoDeal, iWishbag, NepBay and GoGazzab. The study analysed the SERVQUAL Dimensions that influence the customer satisfaction when they make their purchases online by using the aforementioned websites.

Among the 7 dimensions considered as those influencing the online buying satisfaction level of customers, website assurance was found to be most influential. Table 3 shows the mean value and standard deviation of service quality dimensions. Five-point Likert scale was used to analyse their influence where 1 represented 'strongly agree' and 5 represents 'strongly disagree' opinions. It indicates that website assurance is the determinant for influencing customer satisfaction as the overall mean score is 1.67 implying that respondents have agreed website assurance protects information about their web-shopping behaviour. 
Table 3

Descriptive Analysis of Variables (SERVQUAL Dimensions)

\begin{tabular}{llllll}
\hline Descriptive Statistics & Minimum & Maximum & Mean & s.d. & $\begin{array}{l}\text { Mean-based } \\
\text { Ranks }\end{array}$ \\
\hline Website Information & 1 & 5 & 2.16 & 0.96 & 3 \\
Website Usability & 1 & 3 & 1.82 & 0.52 & 2 \\
Website Reliability & 1 & 4.5 & 2.65 & 1.24 & 6 \\
Website Responsiveness & 2 & 4 & 2.54 & 0.56 & 4 \\
Website Assurance & 1 & 4 & 1.67 & 0.62 & 1 \\
Website Transaction Security & 1 & 4 & 1.82 & 0.73 & 2 \\
Website Personalisation & 1.5 & 5 & 3.15 & 1.20 & 7 \\
Customer Satisfaction (from online & 2 & 5 & 3.02 & 0.97 & - \\
purchases) & & & &
\end{tabular}

Note. Data from survey conducted in 2017

Ranked by their influence the online buying satisfaction level of customers, website assurance is followed by the dimensions of Website Transaction Security, website usability and website information.

While the mean score with 3.15 indicating the lowest influence on customer buying satisfaction level among dimensions is website personalisation because respondents feel that the website does not offer personal discounts/offers based on the past purchases. As a whole, it can be analysed that customers in Kathmandu valley are not so satisfied with the online shopping experience.

Table 4

Correlation Analysis

\begin{tabular}{lll}
\hline & Correlation Coefficient & P-Value \\
\hline Website Information (X1) & 0.392 & 0.000 \\
Website Usability (X2) & 0.092 & 0.200 \\
Website Reliability(X3) & 0.266 & 0.000 \\
Website Responsiveness (X4) & 0.040 & 0.612 \\
Website Assurance(X5) & 0.267 & 0.001 \\
Website Transaction Security(X6) & 0.270 & 0.001 \\
Website Personalisation(X7) & 0.103 & 0.194 \\
\hline
\end{tabular}

Note. Data from survey conducted in 2017

Table 3 shows the correlation between the SERVQUAL dimensions and customer online buying satisfaction level. The correlation coefficient between website information and customers buying satisfaction is 3.392 indicating that there is positive correlation between these variables. While the corresponding $p$-value is 0.000 signifying there is a statistically significant relationship as the p-value is less than 0.05 level of significance. 
Website usability and customer satisfaction level is positively correlated as the $r$-value is 0.092 with the $p$-value 0.200 signifying there is no statistically significant relationship between them. Likewise, the correlation coefficient between website reliability and customer satisfaction level is 0.266 which indicates that they are positively correlated. The $p$-value between them is 0.000 showing a statistically significant relationship as the $p$-value is lower than level of significance 0.05 .

Similarly, the correlation coefficient between website responsiveness and customer satisfaction level is 0.040 signifying positive correlation. The p-value is 0.612 which is more than 0.05 level of significance. Website assurance and customer buying satisfaction is also positively correlated as the r-value is 0.267 . The $p$-value of 0.001 indicates that there is a statistically significant relationship between them, as it is less than 0.05 level of significance.

Table 5

Summary of Hypotheses

\begin{tabular}{lll}
\hline Statements & $P$-value & Remarks \\
\hline $\mathrm{H}_{01}: \begin{array}{l}\text { There is no significant relationship between website information } \\
\text { and customer's online buying satisfaction }\end{array}$ & 0.000 & Not accepted \\
$\mathrm{H}_{02}: \begin{array}{l}\text { There is no significant relationship between website usability } \\
\text { and customer's online buying satisfaction level }\end{array}$ & 0.200 & Accepted \\
$\mathrm{H}_{03}: \begin{array}{l}\text { There is no significant relationship between website reliability } \\
\text { and customer's online buying satisfaction level }\end{array}$ & 0.000 & Not accepted \\
$\mathrm{H}_{04}: \begin{array}{l}\text { There is no significant relationship between website } \\
\text { responsiveness and customer's online buying satisfaction level }\end{array}$ & 0.612 & Accepted \\
$\mathrm{H}_{05}: \begin{array}{l}\text { There is no significant relationship between website assurance } \\
\text { policies and customer's online buying satisfaction level }\end{array}$ & 0.001 & Not accepted \\
$\mathrm{H}_{06}: \begin{array}{l}\text { There is no significant relationship between transaction security } \\
\text { and customer's online buying satisfaction level }\end{array}$ & 0.001 & Not accepted \\
$\mathrm{H}_{07}: \begin{array}{l}\text { There is no significant relationship between website } \\
\text { personalization and customer's online buying satisfaction level }\end{array}$ & 0.194 & Accepted \\
\hline
\end{tabular}

Note. Data from survey conducted in 2017

In the same way, the correlation coefficient between website transaction security and customer satisfaction is 0.270 indicating positive relationship. The corresponding $p$-value is 0.000 which is lower than level of significance 0.05 . It indicates that there is a statistically significant relationship between website transaction security and customer buying satisfaction level. However, there is no statistically significant relationship between website personalisation and customer buying satisfaction level as the p-value is more than level of significance 0.05 while they are positively correlated.

Thus, all dimensions are positively correlated with the dependent variable, i.e., customer satisfaction indicating increase in SERVQUAL dimensions increases the 
customer buying satisfaction level. Since, the p-value of the website information, website reliability, website assurance and website transaction security are less than 0.05 level of significance representing there is a statistically significant relationship with customer's online buying satisfaction which implies that these dimensions have an influence on customers for purchasing online. Meanwhile, Website usability, website responsiveness and website personalisation has not statistically significant influence on customer's online buying satisfaction levels as the $p$-value is more than level of significance 0.05 that signifies these dimensions does not have much influence on purchasing online. So, the finding states that online shopping stores can devote valuable corporate resources in regards with the e-service quality attributes identified in the study.

\section{Conclusion and Implications}

With the purpose of measuring the service quality of online shopping websites on the basis of SERVQUAL model and analysing their influence on customer satisfaction level, this study has been conducted. The results obtained from the descriptive analysis reveal that customers in Kathmandu valley are not so satisfied with the online shopping experience in overall that indicates Nepalese online shopping companies are not taking actions and making strategies to increase the number of satisfied clients. Based on this research, only 56.9 per cent of the total respondents were satisfied with buying products online. According to the correlation analysis, among seven dimensions of SERVQUAL taken in this research, website information, website reliability, website assurance and website transaction security are found to be significant predictors of customer satisfaction. This implies that these are the factors which influence most to the customer satisfaction while buying through online in the Kathmandu Valley. Despite the insignificant relationship between dimensions like website usability, website responsiveness and website personalisation and dependent variable, i.e., customer buying satisfaction level, the correlation coefficient concludes that they are positively correlated.

This conclusion attempts to validate with the research of Xiao and Lu (2017) in which the author concluded that service quality of online shops is half of success in business organisation. And this research also argued online websites provide better website reliability like delivery of the ordered goods, quick delivery and shows in action what is promised, it will increase the level of online buying satisfaction of customers which ultimately leads to business success.

The present study contradicts with the study undertaken by Elias (2015) and Kharel (2018). According to the study of Elias (2015), personalisation has significant influence on customer satisfaction while information quality may not affect customer satisfaction buying through online. This could be due to the contextual differences and the field of study done. Likewise, Kharel (2018) also claims that website information does not influence a customer's online purchase decision. While the results from analysis and hypothesis testing in this research 
shows that personalization does not have significant relationship and information quality has significant relationship.

There are several areas where this study can be taken further to gain new insight. In the light of the results, website reliability, responsiveness, assurance and transaction security are recommended to improve more as many consumers are not satisfied with the way Nepalese websites function and also these are the dimensions that influence the most while purchasing online. This would help online websites of Nepal to successfully fulfil the orders they get. Moreover, it argued that cancelling orders for reasons such as not in stock, lost in delivery or damaged during transit is detrimental to customer's satisfaction in online shopping. Such things are considered as the improper functioning of the website and the inability to perform the promised services dependably and accurately in the context of the web. Thus, the finding suggests the marketers maintain good quality service in order to increase satisfaction level of customers. So, website reliability should be considered more. Similarly, this research provides a groundwork for future researchers in studying the consumer behaviour of Nepalese online shoppers. Further research can be possible by increasing sample size and identifying variables or any other dimensions of service quality or other models than SERVQUAL for analysing customer online buying satisfaction level as it might have some limitations.

\section{References}

Chang, H. H., \& Wang, H. W. (2010). The moderating effect of customer perceived value on online shopping behavior. Emerald Insight, 2(5), 22-35. Retrieved from: https://doi.org/10.1108/14684521111151414

Delima, A., \& Ashary, H. M. (2019). Influence of service quality, product quality, price, brand image, and promotion to Consumer Satisfaction Affecting on Consumer Loyalty. SSRN Electronic Journal. Retrieved from https://papers.ssrn.com/sol3/ papers.cfm?abstract_id $=3308707$

Elias, N. F., Mohamed, H., \& Arridha, R. R. (2015). A study on the factors affecting customer satisfaction in online airline services. International Journal of Business Information Systems. 20(3), 274-288. DOI: 10.1504/IJBIS.2015.072249

Kharel, B. (2018). Factors influencing online brand trust: Evidence from online buyer in Kathmandu valley. Journal of Business and Social Sciences Research, 3(1), 4764. Retrieved from: https://doi.org/10.3126/jbssr.v3i1.24841

Kloppers, S. R. (2014). Investigating factors influencing customer online buying satisfaction in Gauteng, South Africa. International Business \& Economics Research Journal, 13(5), 1187-1198. Retrieved from: https://doi.org/10.19030/iber. v13i5.8784

Liu, X. (2008). An empirical study of online shopping customer satisfaction in China: A holistic perspective. International Journal of Retail \& Distribution Management, 36(11), 919-940. DOI: 10.1108/09590550810911683 
Stervice Quality Dimensions Influencing Online Buying Satisfaction... : Bohra, Tamang

Pappas, I. O., Pateli, A. G., Giannakos, M. N., \& Chrissikopoulos, V. (2013). Moderating effects of online shopping experience on customer satisfaction and repurchase intentions. International Journal of Retail \& Distribution Management, 33(2), 161175. DOI: 10.1108/IJRDM-03-2012-0034

Parasuraman, A. P., Zeithaml, V. A., \& Berry, L. L. (1985). A conceptual model of service quality and its implication for future research (SERVQUAL). Journal of Marketing, 49(1), 41-50. DOI: 10.2307/1251430

Sthapit, A. (2016). International business: Text \& cases $\left(5^{\text {th }}\right.$ ed). Kathmandu: Taleju Prakashan.

Tandon, U., Kiran, R., \& Sah, A. N. (2015). Customer satisfaction using website functionality, perceived usability and perceived usefulness towards online shopping in India. UK: Sage Publications. Retrieved from: https://doi. org/10.1177\%2F0266666915621106

Xiao-ping, L., \& Lu, L. M. (2017). Service quality of online shops and express impact on customer satisfaction: Under e-commerce environment. School of Economics and Management. Retrieved from: https://doi.org/10.1109/ICSSSM.2014.6874099

Zhang, $\mathrm{H}$. (2016). The antecedents of customer satisfaction relation to attitude and loyalty towards online shopping: A case study in Guangzhou, China (Unpublished Master's Thesis). School of Business, University of the Thai Chamber of Commerce, Thailand. Retrieved from: https://searchlib.utcc. ac.th/library/ onlinethesis/262881.pdf

\section{Acknowledgement}

NA

\section{Funding}

No funding was received for this research.

\section{Conflict of interest}

The authors claim that they have no conflict of interest because of their affiliation and other formal positions

\section{Editorial Disclaimer}

The Journal's editorial team makes no warrantee with respect to technical accuracy and completeness of the data and their analysis in the papers. The editorial team specifically disclaims any implied warrantee of fitness of the study and analytical tools thereof for any particular purpose, as the editors shall not intend to vouch that all authors have made exhaustive efforts in incorporating all the editorial and reviewer comments communicated to them during the editing process. 